International Journal of Social Sciences and Management Review

ISSN 2582-0176

\title{
FACTORS INFLUENCING JOB SATISFACTION TO EMPLOYEES IN TANZANIA
}

\author{
JESCA MONGI \\ Mzumbe Mbeya Campus College, P.o.Box 6559 Mbeya, Tanzania
}

https://doi.org/10.37602/IJSSMR.2020.3404

\begin{abstract}
Job Satisfaction is an important aspect for every organization so the main aim of this study is to examine the influence of workload and salary on job satisfaction toward employees. The objective of this study is to examine the influence of every independent variable on job satisfaction. The study involved 100 numbers of employees. This is quantitative research so in order to analyze the data that been collected Statistical Package for Social Science (SPSS) has to be used in order to see the relationship between independent variables which is workload and salary on dependent variable which is job satisfaction. This article had recognized the workload as a factor that may influence job satisfaction. According to the multiple regression analysis, every independent variable got a positive relationship with dependent variables but what makes it differences was workload does not have a significant positive relationship with job satisfaction compared to salary. More importantly, based on findings salary will positively influence job satisfaction but for the workload case, these variables will not positively influence job satisfaction. Finally recommended that the organization should play a significant role in order to keep their employee satisfy because it may bring so many benefits to the organization conclusion provided to the organization.
\end{abstract}

Keywords: Job satisfaction; workload and salary Tanzania

\subsection{INTRODUCTION}

According to Vroom (1964), a job can be described as a particular task, duty or function that someone performs or does to earn money and regardless of which area or sector the person being employed to, the job must be carried out with the highest level of responsibility and honesty. The sole reason behind it is to attain job satisfaction which is an important aspect to be achieved in the first place. There are numerous different concept of job satisfaction were developed by different scholars. According to Locke (1969), job satisfaction was a pleasurable or positive emotional state resulting from the appraisal of one or job experiences and Hoppock (1935) defines job satisfaction as a level of physiological, psychological and environmental circumstances which may influence the level of job satisfaction among employees. Moreover, the most frequently quoted meanings on job satisfaction that has been cited is from Spector (1997). According to him satisfaction on the job is how individuals sense about their job from the different viewpoints. 


\section{International Journal of Social Sciences and Management Review}

Throughout so many years, many management divisions wish to achieve a high level of job satisfaction among the employees via employees' incentive, change of working environment and another type of organizational policies. But, are these policies and incentive bring a difference to employees' job satisfaction or does it merely serves as momentary attitude adjustment among the employees? In the modern age, various organizations are looking for ways to improve the job satisfaction via the implementation of several motivational factors. The high level of job satisfaction among employees is an important aspect for the organization since it directly influences the employees and the organization itself. The high satisfaction of employees toward their task or job will create confidence, loyalty and at the end of the day, will lead to the improvement of quality in output by the employees. It is apparent that an efficient and effective organization requires highly committed and motivated employees. Other than that, in today's competitive environment, every organization must stay focus and embrace every challenge carefully because employees' job satisfaction will influence the organization itself in the first place. So, the lack of employees' job satisfaction will affect the supposed organization in negative ways. More importantly, due to the upcoming transformation that this studied organization will implement, it is important for them to understand the factor that will contribute towards employees' job satisfaction to keep the employees satisfied and focused on their job as one of the important assets of the organization is an employee and the cooperation between both parties, employers and employees will help the organization to achieve their vision and mission (Rao, 2017).

Employees differ in the context of a contributing factor that influences their level of job satisfaction. Therefore, this study aims to study the factor that the researcher believes will influence and contribute to employees' job satisfaction at the targeted organization. Subsequently, workload, salary and co-workers are the factors that will influence the level of employee job satisfaction. Therefore, the mentioned variables have been selected due to the study conducted by the Job Street which suggested that workload, salary and co-workers are the factors that will influence the level of happiness among employee on their work and Markovits, Boer, and Dick, (2014); Benjamin, Heffetz, Kimball and Szembrot (2014) stated that when an employee is happy with their job, it will increase the level of job satisfaction among them. The previous studies mentioned above led to this study because the aims of this study is to see the relationship between workload and salary and how all of these factors will influence the level of job satisfaction among employees at the targeted organization. There are various studies concerning job satisfaction and its effect towards organization but this study has not been done in this study's targeted organization. After considering this factor, the researcher decided to take this opportunity to conduct research on the factors that will influence employee job satisfaction in this organization.

\subsection{Job Satisfaction}

First of all, without a doubt, the study about job satisfaction is one of the studies that keep been doing and this is because according to Pan (2015) the study of job satisfaction will provide valuable information about the key factor that will drive toward employee's satisfaction because there are so many factors that may affect employee job satisfaction (Yadav \& Dabhade, 2014). Then, job satisfaction is about the individual sense about their job which is the amount to what individuals happy or not happy in their job and Binder and Coad (2012) found happiness toward job will increase the level of job satisfaction among 


\section{International Journal of Social Sciences and Management Review}

employee. Moreover, job satisfaction has also been referring as an attitude or feelings that people will feel about their work which is positive and favourable attitudes towards the job will lead toward job satisfaction and negative and unfavorable attitudes towards the job will lead to job dissatisfaction just like been mentioned by Asegid, Belachew and Yimam (2014) and this supported by the Robbins and Judge (2013) which is job satisfaction will create a positive perception of a particular job and more important job satisfaction is crucial for organization performance (Budihardjo \& Mulya, 2013). Other than that, Noah and Steve (2012) found on their study employees who have a high level of job satisfaction will hold a positive perception of his or her job and on the opposite employees that have a low level of job satisfaction tend to perceive their job negatively because if employees satisfied and enjoyable in doing their job it will make employees be more fulfilled with their job and Liu, Tang and Yang (2013) found in their study that motivation will play an important role in the job satisfaction which is high motivation will lead toward job satisfaction and low motivation will lead to dissatisfaction because according to Eliason (2011) employee need to satisfy with their job in order to achieve job satisfaction

\subsection{Workload}

The workload we can define as types of work that employee need to perform and this included job duties, job responsibilities, and job scope and usually, every employee got their own job responsibilities that they need to complete it and according to BMJ Quality and Safety workload can be divided at least into three types of workload such as unit-level workload, job-level workload and task level workload. Tregaskis, Daniels, Glover, Butler and Meyer (2012) found that work overload will happen when employees receive workload that beyond their capabilities because of the increase of productivity and performance demand. Lu, Luo, Wang, Le and Shi (2015) found in large organization employees always received several tasks and it needs to be completed within a short period of time and Moen, Lam, Ammons and Kelly (2013) added the combination of deadline and work overload will make job become more stressful and he further added that job stress always occurs when many tasks been given and employees also need coping with the tight deadline of each task combine with the high expectation from the organization. Moreover, few studies have examined the impact of the workload and according to Droogenbroeck, Spruyt and Vanroelen (2014) workload will lead toward fatigue and error at the work because workload may lead toward emotional exhaustion (Tavares \& Eva, 2012). This is supported by Yurur and Sarikaya (2012) which indicate that workload will play an important role in emotional exhaustion.

Other than that, as we know in the organization the employees will consist of different age or generation and every generation got different in term of opinion or perception and according to Lai, Chang and Hsu (2012), there are different perception from generation $\mathrm{y}$, $\mathrm{x}$ and baby boomers toward workload which is generation y and baby boomers perceive when workload getting heavier their quality of work-life will be lower but generation $\mathrm{x}$ perceive this thing differently which is generation $x$ perceive workload will not affect their quality of work life. Then, Ilies, Huth, Ryan and Dimotakis (2015) found that work overload will bring family conflict toward employees and usually this problem may occur toward employees who have a heavy workload and unable to balance it between work and family responsibilities and this being supported by Molino, Cortese, Bakker and Ghislieri (2015) which is they found there is 


\section{International Journal of Social Sciences and Management Review}

a positive relationship between workload and family conflict. More importantly, because of the market competition, the increasing of employee's workload seems to become common issues in the workplace so these problems already become a threat to the organizations in the form of poor performance and lack of ability to reach standards and this happening because of the high number of workload. Bruggen (2015) found employee performance will decrease if the number of workloads was high but the employee will show the high level of performance if there are moderate levels of workload and Long, Kowang, Ping and Muthuveloo (2014) indicated workload will bring stress to the employee and this will impact employee performance and in the same time workload is one of the factors that will not affect job satisfaction among employee in a positive way which is Nilufar, Zaini, David and Syed (2009) found on their study other than homework interface, role ambiguity and performance pressure the other factor that may affect job satisfaction was workload pressure.

\subsection{Salary}

Salary is one of the compensation components and according to Odunlade (2012) compensation can be divided into two components which are cash compensation and fringe compensation. Therefore, paying the right amount of salary according to the market allows a company to attract worker or employees with experience and high level of skill and this can be achieved by interesting types of benefit that been offered by the organization since employee salary also will become an attraction factor to the employee and this result been found by (McGinley, Hanks \& Line, 2017) and more importantly the level of job satisfaction among employees related to the number of salaries that they receive (Yang, Brown \& Moon, 2011). Moreover, there are difference in salary level between gender and this result been found by Crothers et.al (2010) which is they indicated that females employees earn less than male employees and Gillum, Mendoza and Marmo (2013) found on their study women earned salary less than their male counterparts and according to Leibbrandt and List (2015), this is because women are less likely to negotiate higher salary compare to their male counterpart. Some of the studies also found a difference in term of salary expectation between females and males employees and this result been found by Schweitzer, Lyons, Kuron and $\mathrm{Ng}$ (2014) which is female had lower salary expectation than their male counterpart. Other than that, employees with experience with a combination of high skill and knowledge will lead to a better result for the company, for example, increasing the level of productivity and this will increase company's revenue or profit and organization can achieve this by offering the competitive and interesting level of salary to the employees (Vidal Salazar, Cordon Pozo \& Torre Ruiz, 2016).

More importantly, Christ, Emett, Tayler and Wood (2016) mentioned that for so many years money have been used to motivate the employee and help achieve organization goal but according to Stillo and $\mathrm{Ph}$ (2011) sometime organization failed to manage this thing carefully and it may affect the organization in negative ways. Sharma (2011) found this which is in terms of salary satisfaction a significant difference is noticed between the public sector and private sector organization and because of that employee at public sector have higher job satisfaction compared to the employee from the private sector. More importantly, no one work for the free and interesting level of salary may improve employees performance in positive ways and Blaga \& Jozsef (2014) indicated that interesting amount of salary will be a driving force to improve employees performance in positive ways and organization need to 


\section{International Journal of Social Sciences and Management Review}

implement the right strategies in order to survive in the current competitive market environment which is $\mathrm{Li}$ and Tan (2013) mentioned that organization strategies may influence business performance and one of the aspects that organization need to taking care is employees itself.

\subsection{Underpinning theory}

Maslow's hierarchy of needs theory was developed by Abraham Maslow and this theory classified human needs into five aspects which are physiological needs, safety needs, love and belongingness needs, esteem needs and finally self-actualization needs. Mullin (2002) further explained this theory and based on his study, the bottom level is the lowest level of need which is physiological need while self-actualization needs is the highest form of need in the hierarchy. Kaur (2013) defined physiological safety, love and belongingness need as deficiency needs while esteem and self-actualization need as growth needs. Kaur (2013) also mentioned Maslow's model may help a manager to understand his or her employee more and more importantly, will encourage them more precisely. Other than that, according to Maslow's hierarchy of need theory, every human action has their own motivation and in order to maximize the level of satisfaction, the multiple motivation factor needs to be fulfilled. According to the Mullin (2002), the level of satisfaction among people are related to needs, desires, want, expects, deserves or deems to be his entitlement and by using this theory it was possible to know every motivation factors that had been classified by the Maslow that will affect the level of satisfaction among people since different people has different motivation factor that will drive them toward satisfaction.

A workload is part of the security need in the Maslow's hierarchy of need as employees demand fair work practices and need to receive fair treatment in their employment. As indicated by Colquitt et al. (2013), employees who feel fairly treated are more committed toward their organization and a manager needs to play a key role in treating the employees fairly in order to inculcate employees' positive perception toward the management and the organization as a whole (Rupp, Shao, Jones \& Liao, 2014). More importantly, Ndjaboue, Brisson and Vezina (2012) found in their study, it is crucial to make sure employees are satisfied with the distribution of the workload in their job.

Salary is another important factor to be considered in order to support employees' life in order to fulfil their psychological need. The employees need their salary to fulfil their essential needs such as food and house. Saeed et al. (2013) stated in his study that money will play an important role in the job satisfaction among employee since everyone needs money and according to him, the power of money should not be underestimated. Moreover, according to Mohanty (2014), a high income also become one of the factors that will lead to happiness because money will help a person meeting the basic needs, fulfil psychological needs and more importantly this will increase satisfaction in their life. Moreover, the relationship with co-workers is a part of the Maslow of the hierarchy of need and it can be regarded as love and belongingness needs which suggested employees' need to be respected, love and care by others and this can be achieved when a person is capable of having an affiliate with another person in a meaningful way (Carducci, 2009). More importantly, Barsade and O'Neill (2014), described that feeling of affection, compassion, caring and tenderness in the workplace are related positively toward employees' satisfaction. 


\section{International Journal of Social Sciences and Management Review}

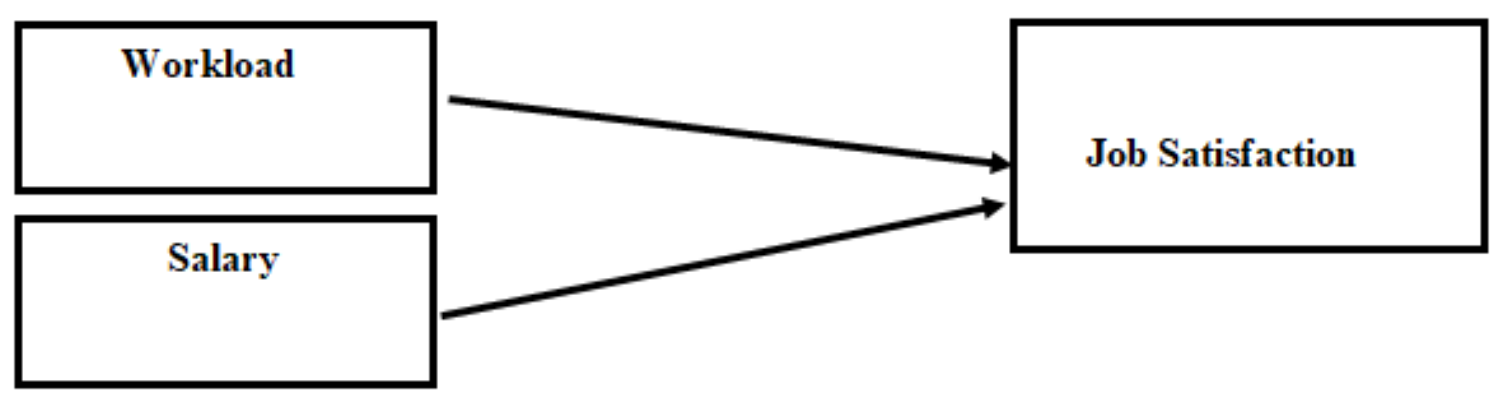

Figure 1.1: Research Framework

\subsection{Workload and job satisfaction}

First of all, the amount of a job's workload itself will bring stress towards the employees and this situation may affect the level of job satisfaction among employees. Hoboubi, Choobineh, hanavati, Keshavarzi and Hosseini (2016) stated in their study; there is a negative relationship between workload and job satisfaction. Moreover, to test the relationship between workload and job satisfaction, Shahzad, Muntaz, Hayat and Khan (2010), has conducted a research of compensation and workload in the Public Education Institution in Pakistan and they stated that there is a negative relationship between workload and job satisfaction. The finding mentioned above is supported by Yeh (2015), who discovered in his study that workload will decrease job satisfaction. Therefore based on the above discussion, the first hypothesis proposed in this study are as follow:

H1: There is a negative relationship between workload and job satisfaction.

\subsection{Salary and job satisfaction}

Firstly, employees' level of salary may play a crucial role to determine the level of employees' job satisfaction in the organization. For instance, an employee hopes to receive fair pay for the job that he or she performed and it may affect the performance and the level of job satisfaction. According to Pruthi et al.(2016), there is a relationship between salary and job satisfaction. Other than that, Sharma (2011) stated in her study that salary satisfaction has already been proven to become one of the important factor that will increase the level of job satisfaction among employees. Other than that, Chai and Nik Intan Norliza (2013) conducted a study among the non- administrative employees at the company X located in Mbeya City to see a relationship between salary and job satisfaction. The result shows that salary is one of the factors that will positively influence the employees' job satisfaction among the nonadministrative employees at the company. Therefore, based on the above discussion, the second hypothesis proposed in this study are as follow:

H2: There is a positive relationship between salary and job satisfaction.

\subsection{Materials and methods}




\section{International Journal of Social Sciences and Management Review}

The population of the study is composed of 130 numbers of employees. Therefore, according to the Morgan table, the sample size should be 108 respondents and in this research, the researcher conducted a survey on the factor that may influence employees' job satisfaction in the studied organization. The researcher distributed a total of 100 questionnaires because the researcher was a concern about the low probability rates of turn up responses. Sampling technique for this study was simple random sampling which means each member of the population has an equal probability of being chosen.

\subsection{Multiple Linear Regressions}

Regression analysis explains correlations analysis in order to determine whether the variables possess more on the positive or negative relationship and at the same time to test the hypothesis. Table 1 shows a summary of the model

Table 1. Model Summary

\begin{tabular}{|c|c|c|c|}
\hline Model $\mathrm{R}$ & R Square & $\begin{array}{l}\text { Adjusted R } \\
\text { Square }\end{array}$ & $\begin{array}{l}\text { Std. Error of } \\
\text { the Estimate }\end{array}$ \\
\hline 1 & $.749^{\mathrm{a}}$ & .549 & .30612 \\
\hline
\end{tabular}

a. Predictors: (Constant), Workload, Salary

Table 1 can be used to determine how well a regression model will fit the data. The $\mathrm{R}$ column will represent the value of $\mathrm{R}$; the multiple correlation coefficients which are R-value can be used to measure the prediction of the dependent variable (Job Satisfaction). R-Value 0.749 will indicate a good level of the prediction. R Square value which is also been called as a coefficient of determination will help to determine the proportion of various independent variables that can be explained by the independent variables. The Value of $R$ Square 0.560 means independent variables explain $56 \%$ of the variability of the dependent variable

Table 2 ANOVA Analysis

\begin{tabular}{|c|c|c|c|c|c|}
\hline Model & $\begin{array}{l}\text { Sum of } \\
\text { squares }\end{array}$ & df & Mean square & F & Sig. \\
\hline 1 Regression & 14.209 & 3 & 4.736 & 50.541 & $.000^{\mathrm{b}}$ \\
\hline Residual & 11.152 & 119 & .094 & & \\
\hline Total & 25.361 & 122 & & & \\
\hline
\end{tabular}

a. Dependent variable : Job Satisfaction

b. Predictors : ( Constant ), Workload, Salary 


\section{International Journal of Social Sciences and Management Review}

The $\mathrm{F}$ ratio in the ANOVA table test will provide the result whether the overall regression model will be fit for the data or not. The table 2 shows that the independent variables statistically significantly predict the dependent variable, $F(3,119)=50.541, \mathrm{p}<.0005$ mean the regression model is a good fit of the data.

\subsection{RESULTS}

Relationship between workload and job satisfaction: Based on the result if a significant level is less than 0.05 , it means that there is a relationship between workload and job satisfaction. Therefore, since the table of coefficient shows that the significant level is higher than 0.05 (0.116), it means there is no positively significant relationship between workload and job satisfaction. This result is similar to the studies by Trivellas, Reklitis \& Platis (2013), Bouckenooghe and Raja and Butt (2013) which stated that workload does not have a positive relationship with job satisfaction since workload will cause job stress to the employee although based on the result there is no significant negative relationship between workload and job satisfaction, Therefore, hypothesis 1 is rejected since there is also no significant negative relationship between workload and job satisfaction.

Relationship between salary and job satisfaction: Based on the result, if a significant level is less than 0.05 , it means that there is a relationship between salary and job satisfaction. Therefore, since the coefficient table shows that the significant level is less than $0.05(0.000)$, it means that there is a positive significant relationship between salary and employee job satisfaction. These results are consistent with the previous study by Smith and Shields (2013); Gurkova et al. (2012) who reported that salary is positively related to employee job satisfaction. In short, hypothesis 2 is accepted; there is a significant positive relationship between salary and job satisfaction.

\subsection{CONCLUSION}

The researcher recommends that the organization offers a competitive salary as offered by most organizations in the market. Therefore, it is crucial to make sure that the employees' salary must be at least similar or better than what their competitors are offering. By looking at this factor, only then the employees will be satisfied. More importantly, the organization should conduct a pay survey in order to know whether their level of payment in the market is competitive or not. More importantly, to implement it successfully, the organization need to play a crucial role by being alert with the matter of whether to use lead policy, market policy or lag policy in the salary analysis.

In the modern workplace, many organizations will seek to have the high productivity in term of their employees' performance and because of this, sometimes employees cannot handle the amount of workload that they need to do which may reduce the level of job satisfaction among employees and the researcher would like to recommend to the organization to follow the following method in order to help the organization manages their employee workload. Firstly, the organization need to be reasonable when distributing the task or responsibility to their employee by taking into account the employees' capabilities to complete the task because different employee comes with different knowledge, skill and expertise so sometimes high expectation from the manager or organization may reduce the level of job satisfaction 


\section{International Journal of Social Sciences and Management Review}

among the employees in the first place. Secondly, the organization may also use training as a method to enhance employees' skill and ability in their job. At certain times, employees may feel stress or burden with their workload due to lack of skill or abilities and by providing training to the employees, it may help them to enhance their knowledge, skill and abilities but prior to the execution of the training, a need assessment needs to do first in order to determine the exact part that needed improvement.

\section{REFERENCES}

Asegid, A., Belachew, T., \& Yimam, E. (2014). Factors Influencing Job Satisfaction and Anticipated Turnover among Nurses in Sidama Zone Public Health Facilities, South Ethiopia Nursing Research and Practice, 2014, 1-26.

Barsade, S. G., \& O’Neill, O. A. (2014). What's Love Got to Do with It? A Longitudinal Study of the Culture of Companionate Love and Employee and Client Outcomes in a Long-term Care Setting. Administrative Science Quarterly, 59 (4), 551-598.

Benjamin, D., Heffetz, O., Kimball, M., \& Szembrot, N. (2014). Beyond Happiness and Satisfaction: Toward Well-Being Indices Based on Stated Preference. American Economic Review, 104 (9), 2698-2735.

Binder, M., \& Coad, A. (2012). Life satisfaction and self-employment: A matching approach. Small Business Economics, 40(4), 1009-1033.

Blaga, P., \& Jozsef, B. (2014). Increasing Human Resource Efficiency in the Production Process. Procedia Technology, 12, 469-475.

Bruggen, A. (2015). An empirical investigation of the relationship between workload and performance. Management Decision, 53(10), 2377-2389.

Bouckenooghe, D., Raja, U., \& Butt, A. N. (2013). Combined Effects of Positive and Negative Affectivity and Job Satisfaction on Job Performance and Turnover Intentions. The Journal of Psychology, 147(2), 105-123.

Budihardjo, A., \& Mulya, P. (2013). The Relationship between Job Satisfaction, Affective Commitment, Organizational Learning Climate and Corporate Performance. GSTF Journal on Business Review, 2(4), 58-64.

Carducci, B. J. (2009). Carducci, B. J. (2009) "The Psychology of Personality: An Overview", The Psychology of Personality:.Viewpoints, Research, and Applications, 3-37.

Chai, H. C., \& Nik Intan Norliza , A. H. (2013). (2013). A Study on the Factors Affecting Job Satisfaction amongst Employees of a Factory in Seremban, Malaysia. Business Management Dynamic, 3 (1), 26-40.

Christ, M. H., Emett, S. A., Tayler, W. B., \& Wood, D. A. (2016). Accounting, Organizations and Society Compensation or feedback: Motivating performance in multidimensional tasks. Accounting, Organizations and Society, 50, 27-40. 


\section{International Journal of Social Sciences and Management Review}

Colquitt, J. A., Scott, B. A., Rodell, J. B., Long, D. M., Zapata, C. P., Conlon, D. E., \& Wesson, M. J. (2013). Justice at the millennium, a decade later: A meta-analytic test of social exchange and affect-based perspectives. Journal of Applied Psychology, 98 (2), 199-236.

Crothers, L. M., Schmitt, A. J., Hughes, T. L., Lipinski, J., Theodore, L. A., Radliff, K., \& Ward, S. (2010). Gender differences in salary in a female-dominated profession. Gender in Management. An International Journal, 25(7), 605-626.

Droogenbroeck, F. V., Spruyt, B., \& Vanroelen, C. (2014). Burnout among senior teachers: Investigating the role of workload and interpersonal relationships at work. Teaching and Teacher Education, 43, 99-109.

Eliason, S. L. (2011). Factors influencing job satisfaction among state conservation officers . International Journal of Police Strategies \& Management, 29 (1) , 6-18.

Gillum, D., Mendoza, I. A., \& Marmo, J. (2013). Salary Indicators for Biosafety Professionals .Applied Biosafety, 18 (3), 106-115.

Gurkova, E., Soosova, M., Harokova, S., Ziakova, K., Serfelova, R., \& Zamboriova, M. (2012). Job satisfaction and leaving intentions of Slovak and Czech nurses. International Nursing Review, 60(1), 112-121.

Hoboubi, N., Choobineh, A. R., Ghanavati, F. K., Keshavarzi, S., \& Hosseini, A. A. (2016). The impact of job stress and job satisfaction on workforce productivity in an Iranian petrochemical industry. Safety and Health at Work, 8(1),67-71 .

Hoppock, R. (1935). Job Satisfaction. New York: Harper and Brothers.

Ilies, R., Huth, M., Ryan, A. M., \& Dimotakis, N. (2015). Explaining the links between workload, distress, and work-family conflict among school employees: Physical, cognitive, and emotional fatigue . Journal of Educational Psychology, 107 (4) , 11361149.

Kaur, A. (2013). Maslow's Need Hierarchy Theory: Applications and Criticisms. Global Journal of Management and Business Studies, 3(10), 1061-1064.

Lai, S. L., Chang, J., \& Hsu, L. Y. (2012). Does Effect of Workload on Quality of Work Life Vary With Generations? . Asia Pacific Management Review, 17(4), 437-451.

Leibbrandt, A., \& List, J. (2015). Do Women Avoid Salary Negotiations? Evidence from a Large Scale Natural Field Experiment . Management Science, 61(9), 2016-2024.

Li, Y., \& Tan, C. (2013). Matching business strategy and CIO characteristics: The impact on organizational performance. Journal of Business Research, 66(2), 248-259.

Liu, B., Tang, T. L., \& Yang, K. (2013). When Does Public Service Motivation Fuel the Job Satisfaction Fire? The Joint Moderation of Person-Organization Fit and NeedsSupplies Fit . Public Management Review, 17(6), 876-900. 


\section{International Journal of Social Sciences and Management Review}

Long, C. S., Kowang, T. O., Ping, T. A., \& Muthuveloo, R. (2014). (2014). Investigation on the Impact of Job Stressors on Nurses in Malaysia. Asian Social Science, 10 (4) , 6777.

Locke,E.(1969).What is job satisfaction? Organizational Behavior and Human Performance, 4(4), 309-336.

Lu, Y., Luo, L., Wang, H., Le, Y., \& Shi, Q. (2015). Measurement model of project complexity for large-scale projects from task and organization perspective. International Journal of Project Management, 33(3), 610 - 622.

Markovits, Y., Boer, D., \& Dick, R. V. (2014). Economic crisis and the employee: The effects of economic crisis on employee job satisfaction, commitment, and selfregulation . European Management Journal, 32 (3), 413 - 422.

Mcginley, S. P., Hanks, L., \& Line, N. D. (2017). Constraints to attracting new hotel workers: A study on industrial recruitment. International Journal of Hospitality Management , $60,114-122$.

Moen, P., Lam, J., Ammons, S., \& Kelly, E. L. (2013). Time Work by Overworked Professionals. Work and Occupations, 40 (2), 79 - 114.

Mohanty, M. S. (2014). What determines happiness? Income or attitude: Evidence from the U.S. longitudinal data . Journal of Neuroscience, Psychology, and Economics, 7 (2), $80-102$.

Molino, M., Cortese, C. G., Bakker, A. B., \& Ghislieri, C. (2015). Do recovery experiences moderate the relationship between workload and work-family conflict? Career Development International, 20 (7), 686 - 702.

Mullins, L. J. (2002). Management and Organisational Behaviour. 6th edition. New Jersey: PrenticeHall.

Ndjaboue, R., Brisson, C., \& Vezina, M. (2012). Organisational justice and mental health: A systematic review of prospective studies. Occupational and Environmental Medicine, 69 (10) $694-700$.

Nilufar, A., Zaini, A., David, Y. G., \& Syed, S. (2009). Study of Job Stress on Job Satisfaction among University Staff in Malaysia: Empirical Study. European Journal of Social Sciences, 8(1), 121-131.

Noah, Y., \& Steve, M. (2012). Work environment and job attitude among employees in a Nigerian work organization . Journal of Sustainable Society, 1 (2), 36 - 43.

Odunlade, O. R. (2012). Managing Employee Compensation and Benefits for Job Satisfaction in Libraries and Information Centres in Nigeria. Library Philosophy and Practice. Retrieved from http://unllib.unl.edu/LPP/tella2.htm

Pan, F. C. (2015). Practical application of importance-performance analysis in determining critical job satisfaction factors of a tourist hotel . Tourism Management, 46, 84 - 91. 


\section{International Journal of Social Sciences and Management Review}

Pruthi, N. R., Deal, A., Langston, J., Kirby, E. W., Gonzalez, C., McKenna, P, Pruthi, R.

S. (2016). Factors Related to Job Satisfaction in Urology. Urology Practice, 3 (3), 169 - 174.

Rao, M. (2017). Innovative tools and techniques to ensure effective employee engagement. Industrial and Commercial Training, 49 (3), 127 - 131.

Robbins, S. P., \& Judge, T. A. (2013). Organizational behavior. New York: Pearson Education, Inc.

Rupp, D. E., Shao, R., Jones, K. S., \& Liao, H. (2014). The utility of a multifoci approach to the study of organizational justice: A meta-analytic investigation into the consideration of normative rules, moral accountability, bandwidth-fidelity, and social exchange. Organizational Behavior and Human Decision Processes, 123(2), 159-185.

Saeed, R., Lodhi, N. R., Iqbal, A., Nayyab, H. H., Mussawar, S., \& Yaseen, S. (2013). Factors Influencing Job Satisfaction of Employees in Telecom Sector of Pakistan . Middle-East Journal of Scientific Research, 16(11), 1476-1482.

Schweitzer, L., Lyons, S., Kuron, L. K., \& Ng, E. S. (2014). The gender gap in pre-career salary expectations: A test of five explanations . Career Development International, 19(4), 404-425.

Shahzad, K., Mumtaz, H., Hayat, K., \& Khan, M. A. (2010). Faculty workload, compensation management and academic quality in higher education of Pakistan: Mediating role of job satisfaction. European Journal of Economics, Finance and Administrative Science, $27,450-2275$.

Sharma, J. P. (2011). Salary Satisfaction as an Antecedent of Job Satisfaction: Development of a Regression Model to Determine the Linearity between Salary Satisfaction and Job Satisfaction in a Public and a Private Organization. European Journal of Social Sciences, 18(3), 450-461.

Smith, D. B., \& Shields, J. (2013). Factors Related to Social Service Workers Job Satisfaction: Revisiting Herzbergs Motivation to Work. Administration in Social Work, 35(2), 105-115.

Spector, P. (1997). Job Satisfaction: Application, Assessment, Causes and Consequences. Thousand Oaks, CA. Sage Publications.

Stillo, S. (2011). The Role of Salary as a Motivating Strategy for Increasing the Quality and the Stability of the Public Administration in Albania. International Journal of Economic Perspectives , 5(1), 5-15.

Tavares, W., \& Eva, K. W. (2012). Exploring the impact of mental workload on rater- based assessments. Advances in Health Sciences Education, 18(2), 291-303.

Tregaskis, O., Daniels, K., Glover, L., Butler, P., \& Meyer, M. (2012). High Performance Work Practices and Firm Performance: A Longitudinal Case Study . British Journal of Management, 24(2), 225-244. 


\section{International Journal of Social Sciences and Management Review}

Trivellas, P., Reklitis, P., \& Platis, C. (2013). The Effect of Job Related Stress on Employees' Satisfaction: A Survey in Health Care. Procedia - Social and Behavioral Sciences, 73, 718-726.

Vidal-Salazar, M. D., Cordón-Pozo, E., \& Torre-Ruiz, J. M. (2016). Flexibility of benefit systems and firms' attraction and retention capacities . The International Journal, 38(4), 487-504.

Vroom, V. (1964). Work and Motivation. New York: John Wilely and Sons.

Yadav, R. K., \& Dabhade, N. (2014). Work Life Balance and Job Satisfaction among the Working Women of Banking and Education Sector - A Comparative Study. International Letters of Social and Humanistic Sciences, 21, 181-201.

Yang, S., Brown, G. C., \& Moon, B. (2011). Factors Leading to Corrections Officers Job Satisfaction. Public Personnel Management, 40(4), 359-369.

Yeh, H. J. (2015). Job Demands, Job Resources, and Job Satisfaction in East Asia. Social Indicators Research, 121(1), 47-60.

Yurur, S., \& Sarikaya, M. (2012). The Effects of Workload, Role Ambiguity, and Social Support on Burnout among Social Workers in Turkey. Administration in Social Work, 36(5), 457-478. 